\title{
MESSRS. RUTLEY AND WOLLASTON ON DRIFT.
}

Str,--Having examined most of the sections described in my article in the Grou. Mag. for October, 1870, a number of times, especially the sections to which I attached much theoretical importance, I feel called upon to rebut any charge of inaccuracy unaccompanied by instances, with diagrams or detailed explanations. Instead of Mr. Rutley (in your last number) substantiating any such charge, his facts (which I have no doubt have been very accurately observed) corroborate my observations, while any want of theoretical agreement between us consists to a great extent in the application of terms. He calls the small mounds in the lower part of Kentmere " moraine stuff with scratched stones"; I look upon them as an upland extension of the boulder-drift of the plains. He confirms my observations relative to the glaciation and striæ of the higher sides of valleys taking an oblique direction to the "valley axis." This obliquity of direction, however, I have found, in many instances, to extend to the bottoms of the valleys. Mr. Rutley's discovery of striæ crossing the high ground between Kentmere and Long Sleddale, viewed in connexion with my observation of longitudinal striæ, can, I think, be more easily explained by floating ice than by two great ridge-concealing and valley-ignoring ice-streams flowing in different directions at different periods. I cannot agree with Mr. Rutley in calling the stones found in the drift on the high ground between Kentmere and Long Sleddale " moraine stones," and do not believe that moraine matter, properly so called, could ever have been spread over elevated moors, or shed on the summits of high ridges, such as thase which separate the larger valleys of the Lake District. ${ }^{1}$ With regard to the origin of the parallel ridges S.E. of Windermere, Mr. Rutley's remarks, as he himself implies, lead to no definite conclusion on the subject. If he will look for them in the neighbourhood of Windermere, I think he will have no difficulty in seeing several small rocky escarpments, with pinel underneath, like some of the fragmentary cliffs and raised beaches in the Channel Islands and S.W. of England, though differing from them in exhibiting traces of ice-action.

I cannot agree with your other correspondent, Mr. Wollaston, in believing that the able and comprehensive papers by Messrs. De Rance and Ward have well nigh exhausted the subject of drifts and glaciation in the Lake District; and I am sure that these able, accurate, and diligent surveyors would be among the last to entertain any such idea. I have devoted almost exclusive attention to the drifts of N.W. Lancashire, ${ }^{2}$ W. Yorkshire, the Lake District, and the neighbourhood, for two years; and I feel that the whole ground I

1 For remarks on the difference between valley-glacier moraines in which polished and striated stones very seldom occur, and boulder-drifts in which the proportion of such stones, though very variable, is generally considerable, and often very great, see works and papers by Forbes and Lyell (Alps), Close (Ireland), and Jamieson and Milne-Home (Scotland).

2 See paper in Quart. Journ. Geol. Soc., vol. xxv., June, 1869. 
have gone over requires re-examination, and that six years would be too short to enable one person to divide and correlate correctly, and arrive at satisfactory conclusions as to modes of accumulation. In connexion with this subject, I may express my belief that in order to prevent any geologist assigning too much to the depositing power of ice in an extensively glaciated region like the Lake District, it is important that he shonld be acquainted with the drifts of the adjacent plains, and of neighbouring or distant hilly districts in which traces of glaciation are exceptional or altogether absent. It is likewise important that he should not be ignorant of the versatility of the sea as a depositing agent.

The question asked by Mr. Wollaston relative to the absence of Skiddaw slate and granite from Dunmail Raise, applies with nearly equal force to the theory of transportation by great streams of landice. In its bearing on ice-laden marine currents, I think it can be satisfactorily answered. Currents impinging on an island (such as Skiddaw must once have been) do not necessarily flow through all the gaps or passes within sight of the island; and a current may have been prevented from flowing southwards from Skiddaw by an east or west current traversing Keswick and Threlkeld vale. We know that a current laden with boulders from Wasdale Crag flowed over Stainmoor pass, ${ }^{1}$ but no trace of such a current has been found in the Lune valley pass, south of Tebay railway-station. Graniteladen currents must have flowed south and south-west from the Eskdale Fells, but there are no indications of such currents having flowed in any other directions.

Mirlom, $8 t h$ December, $1870 . \quad$ D. Mackintosh.

\section{OBITUARY.}

PROFESSOR BISCHOF, FOR. MEMB. GEOL. SOC., LOND.

Amongst the losses which science has sustained during the past year, it is our melancholy duty to record the death of Professor Bischof, of the University of Bonn, in Rhenish Prussia, who died in that city on the 29 th of November, in his seventy-ninth year. As a tribute of respect to a man of science, of so throughly cosmopolitan reputation, and whose labours have nowhere been more appreciated than in England, we lay before our readers the following short sketch of his scientific career.

Carl Gustav Bischof was born on the 18th of January, 1792, at Wörd, in the suburbs of Nürnberg, in Bavaria, where his father, subsequently Rector of the Latin Sohool of Fürth, then resided. In the Jear 1810 he entered the University of Erlangen, with the special

1 Professor Harkness, in the last number of the Quart. Journ. Geol. Soc., submerges the Lake District to a greater height than 700 feet above the level of Dunmail Raise, and brings up false-bedded marine drift to 1,100 feet above the present sea-level, or 100 feet higher than I have ventured to assert. 